\title{
Severn Bridge
}

\section{SIR GILBERT ROBERTS, G. I. B. GOWRING,}

A. HARDIE \& K. E. HYATT

\section{Sir Gilbert Roberts}

The Joint Engineers for the Severn Bridge scheme, comprising the Severn Bridge itself, the Wye Bridge and eight miles of approach motorways, were Mott, Hay \& Anderson and Freeman Fox \& Partners, and the Consulting Architect was Sir Percy Thomas, OBE, DL. The design of the works described in the Paper was carried out in the office of Freeman Fox \& Partners under the Author's direction.

The Author acknowledges the major part played by his principal assistant, W. C. Brown, OBE, BSc, DIC, PhD, in the evolution and development of the design of the bridge.

Another leading part was played by M. F. Parsons, BSc, MICE, who joined the Author's staff in 1949 and worked on all the various suspension bridge designs and who subsequently served on the site throughout the construction period as deputy Resident Engineer on both contracts.

The Resident Engineers were A. Hardie, MBE, FICE on foundations and B. G. Smith, BSc(Eng), FICE on superstructure.

Among the many members of the staffs of the Joint Engineers who also took part in the work were:

Design staff: D. W. A. Bower, BSc, MICE; P. E. Buckland, BSc, AMICE; P. J. F. Crossley, BA, MICE; D. T. Fern, BSc, MICE (also on site); T. J. R. Gurney, MA, MICE (also on site); M. Howley, MSc, MICE; D. F. McIntosh, AMIStructE; G. F. J. Nash, BA, AMICE (also on site); R. W. Sanders, BSc, MICE (also on site); and W. E. Streeten, BA, MICE.

Site staff: R. F. Bell, BSc, MICE; D. F. Harper, BSc, AMICE; P. A. B. Innes, BSc, MICE; J. C. V. Pryce, MA, MICE; J. M. Whitefield, BSc, MICE; and M. G. Willis, BSc, MICE.

Acknowledgement is also due to the late Sir Ralph Freeman, FICE; the late Sir David Anderson, BSc, LLD, FICE; the late V. F. Bartlett, FICE; and Messrs O. A. Kerensky, CBE, DSc, FICE; C. D. Crosthwaite, BSc, FICE; and J. K. Anderson, MA, FICE, for their work on the earlier scheme, on which the Forth Road Bridge was based.

The Author wishes to express his appreciation of the contributory work of C. Scruton, BSc, and D. E. Walshe, BSc, of the National Physical Laboratory, Aerodynamics Division, who carried out the wind tunnel tests for the Engineers; T. P. Hoar, DSc, FRIC, who advised the Engineers on the protective treatment of the steel and officials of the Meteorological Office who devised the recording instruments used on the Sharpness Bridge.

Finally, the Author wishes to thank C. R. Blackwell, BSc, FICE, for his help in the preparation of the Paper.

\section{Mr Gowring}

The Severn Bridge had two features which were unusual for a major bridge. First, all three foundations in the river which were submerged at high water were exposed at

Papers published: Proc. Instn civ. Engrs, 1968, 41 (Sept.) 1-104. 
low water Spring tides. Second, there was an unusually large current velocity of 7-8 knots on the ebb Spring tide.

Referring to the first aspect, as a result of the rock outcrops on the sites of the East Anchorage and East Pier the foundations were designed for construction as a tidal operation.

On the East Pier the lowest foundation levels at about -18 were only exposed for $\frac{1}{2} \mathrm{~h}$ on Spring tides, i.e. on 7 or 8 occasions each fortnight. Consequently progress in the early stages was very slow and this method would not be economical if rapid construction were critical to the overall programme.

It took four months to construct the first $7 \mathrm{ft}$ of the pier, and during the next four months $34 \mathrm{ft}$ were added to this and this work was no longer tidal.

On currents, the first difficulty encountered was that green concrete placed at low tide needed elaborate precautions to prevent the cement and sand from being washed out leaving only the coarse aggregate.

The next trouble occurred with steel bracing on the stagings. Slender tension members vibrated in the tide and the end connexions failed with a fatigue fracture in some cases within $24 \mathrm{~h}$. The problem was solved by tubular or built-up lattice members whose period of vibration was higher than that of the eddies caused by the current. However, once constructed, the viaducts and stagings which were of allwelded construction fabricated on site stood for over three years with a minimum of maintenance.

\section{Mr Hyatt}

One is always conscious in presenting a paper of the need for compression, and there is a great deal which one might say which has to be left out. For instance, a good deal might have been written of the work on the launching of slipways and the work of removing the extensive river stages on both sides, but $I$ think enough has been stated to give some idea of the problems with which we as contractors were faced.

I should like to have mentioned the help we received from a great many people. We had much assistance on the river from the various harbour authorities who among other things had to make arrangements to close the river to shipping when necessary. The RE detachment put in some very good work and, $I$ think, quite enjoyed it. The work on the slipways involved a number of people, and we received good help from the late Mr Arthur Nicholas and Mr Rowe and all members of Fairfield's staff in the assembling of the sections.

The Severn is a bad river to work on and this was a major physical factor on the site. It exercised us before work was started and we were able to begin consideration of the conditions in good time. In fact, preliminary tests for positioning were made in March 1961 and were not very encouraging. We later found the tidal model of the Severn estuary which had been built at the Hydraulic Research Laboratory, Wallingford, for the benefit of atomic power station construction near the site and this was helpful. We had a report from our marine consultant, Mr Murray Taylor, before we started work on the site, and Hills of Bristol built the curious craft shown in the illustrations. It was capable of moving in any direction and proved to be a great success.

We were able to use the time available to put in hand all our various researches and planning for each operation on the bridge well in advance. Central office did a good job in getting material out, in consultation with the site and plans were available well in advance.

In connexion with the deflexion model which was built at central office, apart from enabling us to decide on the method of erection before it was possible to get out the computer results, it was necessary in order to indicate the areas over which the erection calculations should be made such as the positions of slack suspenders at various stages. 
The tower legs are a splendid piece of design. I would suggest, however, that there could have been a few more horizontal diaphragms in the permanent structure. These diaphragms were up to $70 \mathrm{ft}$ apart and temporary diaphragms had to be provided, erected and dismantled to keep the legs in shape during erection and restrain the vertical joints. This was probably as expensive as extra permanent ones.

Sir Hubert Shirley-Smith, President 1967-8

I sincerely congratulate the Authors of the three Papers on the Severn Bridge. It is designed with a deck only $10 \mathrm{ft}$ deep which is shaped somewhat like an aerofoil to let the wind over and under. Thus it attracts much less wind pressure than other suspension bridges, the decks of which are about $30 \mathrm{ft}$ deep with lattice stiffening.

D2. The bridge also has inclined suspenders which effectively dampen aerodynamic oscillations that would otherwise occur. These two features, with many others, give the bridge an economic advantage which should enable this country to get the design of prestige jobs overseas. I have in mind the proposed new bridges over the Bosphorus and the Messina Straits.

D3. I attended most of the monthly meetings on the Severn site as one of the general managers and part-time on the board, and am pleased to see how much the Contractors benefited from our experience on the Forth.

D4. With regard to tower deflexions at the Severn, tests on models were made in a wind tunnel and the damping device used was very effective so that there were no oscillations at all on the towers and the only deflexion observed was about 2 in. On the Forth Road Bridge there was no warning that the free-standing towers would oscillate in the wind, and in the event they swayed about 90 in. at the top with a period of $4 \mathrm{~s}$. Model tests had been carried out for the Forth Road Bridge, but, owing to some failure in communications, the Contractors were never told and we did not know that any oscillation was to be anticipated.

D5. With reference to the cables, it is said that the final percentage of voids was slightly higher on the Severn than on the Forth. I do not know why that should be, because the Contractors there had the benefit of our making all the comparative plant work properly on the Forth. In addition, we put right all the teething troubles in the highly complex reeling and cable spinning plant and the wrapping machines. This must have saved months of delay which would otherwise have been incurred on the Severn. I calculate that they owe us about $\mathrm{f}+\mathrm{m}$ for all this !

D6. I should like to see as soon as possible the erection of parallel wire cables, not by spinning, but by pulling over strands of parallel wires. I understand a method has been worked out and we shall soon see it done. This might possibly enable cables to be made with their section proportional to the stress throughout their length, which would be a great advance.

D7. In regard to the launching and floating of deck panels to the site, I do not think these panels of steel should ever have been put down in the Severn River and allowed to float around for months in that dirty water. The panels were quite light and it would have been far preferable to float them down on pontoons and lift them up clean and dry. The problem of making a number of deck panels in advance and storing them on dry land could have been easily worked out. It would have cost less and avoided serious risks of corrosion.

D8. On the slinging and erection of the deck panels, I think that Mr G. W. Morley, who was in charge of the Contractors' office in London, deserves a great deal of credit for working out the details of lifting the panels and controlling them so successfully until they could be finally connected up.

D9. It is said that safety was left largely to the Deputy Agent. I think that is wrong and that it should always be the responsibility of the man at the top and never wholly delegated to a deputy or safety officer.

D10. I am interested that wire mesh parapets were used on the catwalks of the Severn Bridge, because they were first used by us on the Forth Road Bridge where 
they saved at least two lives. A man spinning cables at night on a slope in icy weather can slip on the catwalk and roll down $50 \mathrm{ft}$. If there are no wire mesh parapets he will roll over the side into the water. I am interested to know that wire mesh parapets are now being used overseas on the catwalks of the new suspension bridge under construction at Quebec.

D11. In regard to labour relations, we worked out a comprehensive scheme on the Forth and it was closely followed on the Severn with quite good results, and subsequently on the Tay. It was a good arrangement because it included automatic sanctions which hit the pay packet in the event of any illegal stoppage of work.

D12. Last, I should like to know when the painting gantries on the Severn were put up, whether the Contractors wanted to make use of them during erection, and whether they are functioning satisfactorily.

\section{Professor Sir Alfred Pugsley (F)}

The West Country has been waiting for this bridge for over a hundred years and I think it would be appropriate to mention one piece of relevant history.

D14. Brunel had the same problem of crossing the Severn but for railway purposes, and those of us who are accustomed to going through the Severn railway tunnel tend to forget his approach to the problem. He took the railway to South Wales by ferry, and built enormous timber jetties on both sides of the river so that he could operate his steam ferry at all states of the $40 \mathrm{ft}$ tide. These jetties were dismantled after the Severn railway tunnel was built, but their sites can still be traced.

D15. The design wind speed for the new bridge is stated to be $100 \mathrm{mile} / \mathrm{h}$ at deck level. Now Meteorological Office records have recently been analysed by Shellard for many stations in England, including those for an extensive period at Avonmouth, and it is interesting to look at them in relation to the bridge design wind speed.

D16. First, Avonmouth is fairly exposed, and if one were to design for a wind speed equal to that which might occur once in a hundred years, at the level of the deck of the Severn Bridge, the Avonmouth records suggest $115 \mathrm{mile} / \mathrm{h}$, which is noticeably above the $100 \mathrm{mile} / \mathrm{h}$ of the present design. Shellard's records, however, relate to gusts of only three seconds' duration. This is a very short period for giving a bridge the size of the Severn a chance of making its full lateral swing in one direction. If one treats the bridge cable as swinging like a pendulum, its natural period of swing is about $20 \mathrm{~s}$, corresponding to a quarter period of $5 \mathrm{~s}$. This suggests that a $3 \mathrm{~s}$ gust, quite apart from any question of its size, is too short to have real structural effect, and that a 10 seconds' duration gust is more relevant. Taking that argument, the figure of $115 \mathrm{mile} / \mathrm{h}$ at deck level is reduced to $105 \mathrm{mile} / \mathrm{h}$.

D17. In Appendix 2 of Paper 7138 there is reference to wind oscillations of the longer hangers that have been suppressed by a mechanical damping device, the weight of which is not given. I wonder whether Sir Gilbert, looking at the problem again for a new design, would aim to use the same device.

D18. The design stress used in the cables of the Forth Bridge was 40 ton/sq. in. whereas on the Severn Bridge it is stated to be 45 ton/sq. in. Is this just due to greater confidence following further experience and what is the current stress used in the United States for similar cables?

\section{Mr C. D. Crosthwaite, Freeman Fox \& Partners}

I congratulate the Authors on the lucid presentation of their Papers which makes everything sound so easy, which it certainly was not. I would pay tribute to the contractors for the ingenious methods they adopted for constructing the tidal works. They bear all the marks of Gowring's original thinking.

D20. The target contract procedures adopted for the Severn Bridge were popular at the beginning of the war but they fell into disrepute. We should make more use of these procedures and think more seriously of competitive tendering on a target contract basis. 
D21. I was impressed by the precautions taken during the erection of the deck sections to keep aerodynamic instability at bay. This deck erection was difficult enough without the added problem of potential classical flutter. The way it was tackled is one instance out of many of how effective was the partnership of engineer and contractor in the construction of the Severn Bridge. Too often consulting engineers produce marvellous bridge designs and leave the contractor with erection problems to which insufficient thought has been given.

D22. It is indeed correct that the first real attempt to adopt a streamlined box section was when the redesign of Severn Bridge was under way. However, in 1945, when I was working with the late Sir Ralph Freeman, we considered a streamlined shape which had intuitively obvious advantages as regards reduced wind drag and high torsional stiffness. I tried this in our home-made wind tunnel, but the results were disappointing. Compared with the alternative Forth Bridge section, there was a marked lack of aerodynamic damping and the idea was abandoned. At that time not enough wind tunnel testing had been done for such an advanced conception to be carried safely to the design stage.

D23. Sir Gilbert Roberts has indicated that the towers consisted of hollow sections without interior boxes. This was a big advance. Not only was the bending stiffness increased, but the tower sections are much stiffer in torsion than they would otherwise have been.

D24. I should like to say something about the late Dr Frazer with whom I was associated in the early days of the Severn and Forth aerodynamic investigations. He was a very retiring man who did not always receive credit for his work. I note in particular reference to Brotton's computer program, which was used by the contractors. Brotton in his article in the Structural Engineer of May 1966 gives credit to Professor Merchant for suggesting that suspension bridge analysis could be carried out by treating the structure as a plane framework. However, in 1950 Frazer actually developed a matrix method for such analysis and I used it to check some of our ideas on torsional stiffness. This was, of course, before the general availability of computers which made matrix inversion such a simple matter.

D25. Finally, it is not often that one has the opportunity to rethink a design and restart from scratch. Sir Gilbert and his team, in particular Dr Brown, deserve every credit for the way they took advantage of their opportunity.

\section{Mr T. J. Upstone, Redpath, Dorman Long Ltd}

Anyone comparing the deadweight of the Forth Bridge with the Severn Bridge cannot help but be staggered by the great reduction made. Further savings in weight would be equally valuable and it is therefore disappointing to find the same surfacing material specified for the Severn Bridge. Engineers used to specify $1 \frac{1}{2}$ in. of asphalt surfacing, partly because it was thought that that thickness was required to even out the irregularities in what lay underneath the asphalt. Tests were carried out at Severn Bridge on the bare steel plate before and after surfacing on the asphalt. These showed the plate to be far less irregular than the final asphalt surface, so a much thinner surfacing could be used. If a surfacing material weighing $6 \mathrm{lb} / \mathrm{sq}$. $\mathrm{ft}$ instead of $16 \mathrm{lb} / \mathrm{sq}$. ft were used, it would have reduced the dead load by $6 \mathrm{cwt} / \mathrm{ft}$ and the cable tension by some 750 tons in each cable, i.e. by $6 \frac{1}{2} \%$. This should be the spur to find a suitable thin epoxy surfacing for the next large bridge.

D27. Most people are intrigued by the complex machinery and the intricate organization necessary to spin the cables. The costly machinery, the endless trips of the wheel and the miles of wire to be handled on site, always subject to the weather, have prompted the development of a new method of building parallel wire cables from strands prefabricated off the site.

D28. When suspension bridge cables are made up of spiral lay or locked coil ropes, the ropes are made at a factory and sent to the site on reels. At the site they are pulled across the various spans one at a time to be positioned in the cable. The 

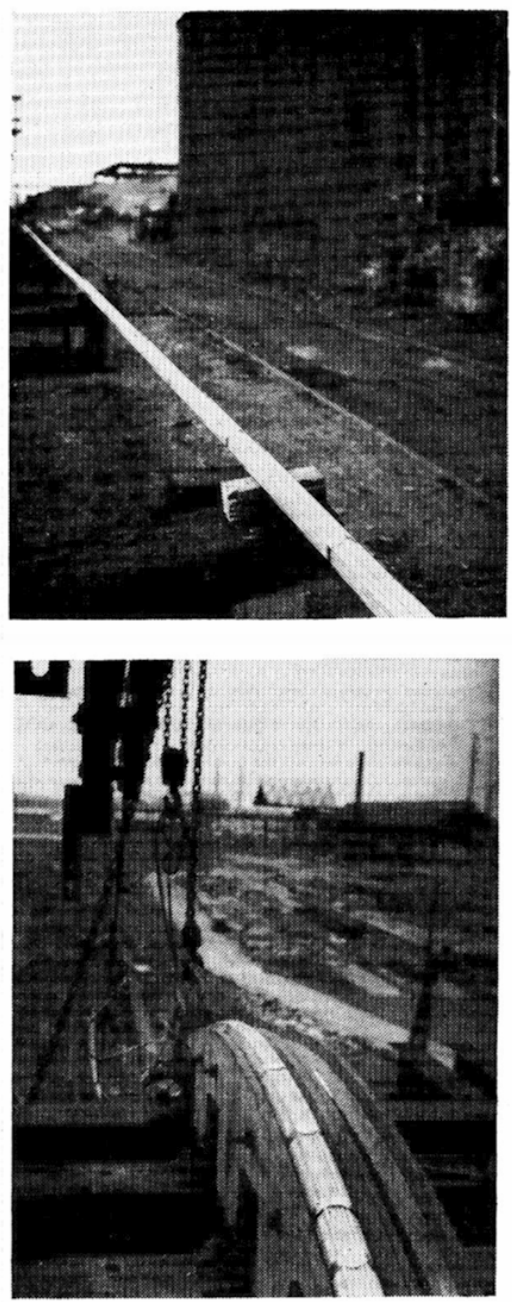

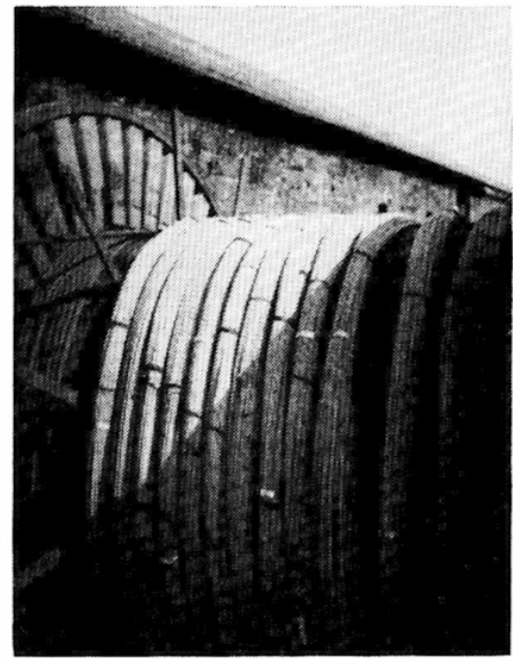

Fig. D1 (above left). 91 wire strand of hexagonal cross section

Fig. D2 (above). Strand wound on drum for transport

Fig. D3 (left). A 'mock up' saddle with strand in position

same can now be done with strands of parallel wires, prefabricated and reeled at a factory or other working space away from the site. Successful tests have been made with a $400 \mathrm{ft}$ long strand composed of 91 wires of $0 \cdot 196 \mathrm{in}$. dia. The strand was made (Fig. D1) and then reeled on to a drum (Fig. D2). It was then unreeled and drawn up and over a tower along the line it would follow if being erected at a bridge. The strand was then placed in a saddle (Fig. D3) at the top of the tower the strand reaching down to ground level in a catenary on each side of the tower. The strand maintained its shape with all wires parallel and was suitable as a constituent part of a suspension bridge cable. It is thought that strands containing a significantly greater number of wires could be made and handled in the same way. Thus the Severn Bridge cables 
could have been made of 61 strands each containing 136 wires. The erection of the strands would not be so severely restricted by inclement weather, and could have been carried out in 50 or 60 working days instead of the $4 \frac{1}{2}$ months taken for spinning wire by wire.

Mr H. S. G. Knox, Deputy Chief Civil Engineer, Cleveland Bridge and Engineering Co. Ltd

I was very pleased to have the opportunity of participating in the construction of this great advance in suspension bridge construction. Working for the contractor, on every project there is, however, something which we would like to see changed or done differently the next time.

D30. With regard to the environment produced by the box deck, the erection of the bridge section was done with very few men. We had about twelve erectors lifting the sections and handling the equipment, and about the same number of welders making transverse site joints, but we needed two or three times that number to back up the erection men because it was a box deck. These men were engaged in rigging and maintaining the lighting and ventilation, in cleaning up preparatory to welding because being a box oil and water collected in it, in cleaning up after the welders, and in making good damage to internal paintwork caused by welding, burning and so on. I do not know the answers to these problems, but different paint treatments might be less liable to damage during construction. It is, however, a factor which might make the bolted rather than the welded site joint more competitive than would seem at first sight.

D31. Sir Gilbert has challenged us to erect two or three sections a day the next time we have a bridge like this. Under suitable river conditions I think it is practicable, but I doubt whether we could economically match this speed of erection in the welding. These twelve welders worked continuously for one year, and to compress that into one month might present a considerable problem. Bolted joints, however, would make keeping pace practicable.

D32. As is normal on carefully engineered suspension bridge construction, no adjustments were necessary to the calculated lengths of the suspenders, so the intention was to leave all the eccentric pins in their nominal position, i.e. with the eccentric part of the pin at about $90^{\circ}$ to the line of stress. However, they would not stay in this position: most slipped to the top dead centre position, i.e. to the maximum plus adjustment to the suspender lengths. Where there is vibration this adjustment cannot be assumed to hold its setting unless some locking is provided.

D33. I was interested ( $\$ 44$, Paper 7138 ) that the design of the deck plates and truss was dictated by the exceptional vehicle load. Forty-five units of HB load produce a 180 ton vehicle, 45 tons per axle and $11 \frac{1}{4}$ tons wheel load. This is substantially greater than the 32 ton vehicle, 14 ton axle and 7 ton twin-wheel loads of the normal American bridge loading, AASHO HS20-44, even when the $30 \%$ impact addition to the latter and the $25 \%$ increase in permissible stress for the BS 153 exceptional load are taken into account. What is the approximate percentage increase in the weight of the deck and of the total steel work of the bridge, and therefore of the cost, caused by the design for the British exceptional load rather than one nearer to United States' practice? Also has any assessment been made of overall effect on the national economy in designing our bridges and roads for vehicular loads which the United States has not felt able to afford?

\section{Mr A. D. Holland, Ministry of Transport}

At the time that the design for the Forth Bridge was finalized, international practice was still having regard to empirical rules recommending minimum values for deflexion and depth of stiffening truss in terms of span. While the Forth Bridge designers had good grounds for doubting the continued relevance of these rules, it is 
understandable that at that stage they felt justified in not casting them completely aside.

D35. Sir Gilbert describes how during the period subsequently available before work on the Severn Bridge was to start, he in effect collected a double bonus. By using a box he had selected the most efficient form in terms of the ratio of torsional stiffness to weight of material, and the reduction in depth which this permitted coupled with the streamlining yielded a substantial reduction in the effect of wind force.

D36. The satisfactory outcome of the wind tunnel tests conducted by the NPL provided evidence not available earlier that stiffness in bending was not the only way in which aerodynamic stability could be reliably ensured.

D37. In $\$ 25$ Sir Gilbert implies that he had perhaps been a little too successful, because to offset partially the reduction in stiffness of the system brought about by reduction in dead weight and therefore in cable tension, the sag ratio was decreased to $1: 12$ from the $1: 11$ used for the Forth Bridge. It would be interesting to know the cost implication of this. What does he estimate the net extra for this may have been?

D38. On the cable spinning it was clear that Mr Hyatt was recognizing some benefit from the experience gained earlier on work at the Forth Bridge, yet in $\S 52$ he gives the average rate of spinning as approximately 5 ton/h of net working time. The comparable figure for the Forth seems to have been about $6 \frac{1}{2}$ ton $/ \mathrm{h}$.

D39. The warning given in $\$ 56$ of Paper 7084 of the susceptibility of high tensile steel to hydrogen embrittlement when subjected to the normal pickling process prior to cadmium plating should be noted.

D40. When he opened the discussion on the Forth Bridge, Sir Alfred Pugsley remarked that it was good to find that Britain was in the forefront of suspension bridge design. It was good too to hear Sir Gilbert outlining his new principle of design to the 170 or so engineers from 23 countries attending the four day international symposium on suspension bridges held in Lisbon in November 1966. That symposium was sponsored by the International Association for Bridge and Structural Engineering, an Association well deserving of support.

D41. Sir Gilbert Roberts has tentatively valued the total financial saving achieved by the box design as against the modified truss at some $£ 900000$. This is the tangible gain in prime cost and could well on another occasion prove an underestimate. There is the saving to be expected in maintenance costs. The area of exposed steelwork at Severn requiring paint protection is approximately half the amount of the modified truss design, and about one third of the amount in the Forth Bridge. In addition to the saving in exposed area, the surface has the advantage of being suitable for the use of spray equipment for painting.

D42. Over and above this is the gain accruing from the enhancement of British engineering prestige. This cannot readily be assessed, but in the long run may perhaps outstrip the cost saving many times over. If so, it will be a splendid tribute to the designers, organizations and individuals associated with the realization of this fine project.

\section{Mr P. S. A. Berridge (F)}

The problems of bridging the Severn and Forth estuaries have been closely linked together since the days of railways, and history has repeated itself in the motorway bridges. In 1864, Fowler and Baker prepared a scheme for a steel (not wrought iron) bridge with a span of $1000 \mathrm{ft}$ to carry the South Wales and Great Western Railway across the Severn; that and two more schemes with slightly shorter spans came to nothing when, in 1872 , the GWR obtained parliamentary powers authorizing the construction of the tunnel which was to take more than 13 years to build and to saddle the railway with an annually recurring expenditure of more than $£ 200000$ to keep it dry. Fowler and Baker took their bridge schemes to Scotland and developed them with the result that the Forth had been bridged in 1890 with the most famous cantilever bridge in the world. 
D44. The Forth Road Bridge, opened in 1964, was designed initially to span the Severn; but; in the end, it was England's good fortune to have the most advanced suspension bridge in the world when the Severn Bridge, with both ends in the county of Gloucestershire, was opened in 1966.

D45. Referring to the welded mild steel saddles (Paper $7084, \S 10$ ), the elimination of the expensive machining operations inseparable from saddles cast in steel shows an important and valuable improvement. Although these saddles were fabricated by Arrols in Glasgow, I, like Mr Hyatt, would pay tribute to the late Arthur Nicholas of Fairfields who was a leading pioneer in the use of automatic welding machines for the fabrication of steelwork; he will be remembered as the builder of the first welded steel trusses used in a main line on British Rail, the $300 \mathrm{ft}$ spans that replaced Brunel's famous 'suspension' trusses in the Chepstow Bridge.

D46. In strong winds the Severn Bridge has to be closed to the passage of tall vehicles because of the risk that they might be blown over. Although the builders of the bridge are not at fault, any periodical interruption in an important line of communication is not a thing to be tolerated in any system involving modern transport; and, I think that in a future bridge, the problem might be solved by deepening the streamlined deck units sufficiently to accommodate such vehicles inside the steelwork where they would be safely out of the wind.

\section{Mr Ford, Ministry of Transport}

The cable spinning process is rather protracted and difficult. On the Forth Bridge they were able to take four bights of wire over instead of two, so that presumably the gear is capable of carrying this weight of wire. I should like to ask why 0.276 wire was not used instead of 0.196 wire. Having twice the area it would have needed half the number of traverses and presumably the cable spinning operation would have been shortened considerably.

\section{Professor S. R. Sparkes, Imperial College of Science and Technology}

I am surprised that the box form was not adopted long before now. It seems that the NPL arrived at this form after the failure of a lattice construction in the wind tunnel. With regard to the wind tunnel tests, I presume these were carried out when the bridge was loaded and unloaded and the appropriate wind conditions were used in design.

\section{Mr C. Scruton, Aerodynamics Division, NPL}

I should like to add my tribute to the designers and contractors engaged in this project. My colleagues and I have been very pleased to have been associated with the Severn Bridge, and to have made in some respects contributions to the design and to the erection procedures. If the Severn Bridge itself has set a trend in design, it certainly has set a trend in the type of aerodynamic investigation for such bridges. In particular we are now much more concerned with wind effects during the erection stages of the bridge than when the bridge is completed, and we have now taken into account the classical flutter of a suspension bridge of this kind.

D50. During the progress of the aerodynamic investigation Sir Alfred Pugsley asked me whether we had considered the classical flutter of the Severn Bridge. At that time we had not, but we did proceed to make an experimental study. This type of instability involves interaction between at least two degrees of freedom. We also studied it theoretically and estimated a critical wind speed of about $150 \mathrm{mile} / \mathrm{h}$ for the completed bridge, which seemed satisfactory. Later on we had to consider the erection stages. In the first calculation we assumed that the segments would be suspended without structural interconnexion and found that in this condition the bridge would flutter at a critical wind speed of about $50 \mathrm{mile} / \mathrm{h}$. This low speed arose 
largely because of the low natural frequencies and because of the approach of the torsional and vertical bending frequencies to unity in this condition. Therefore we had to recommend that the bridge should be stiffened in torsion during erection, and that is why the segments were torsionally interconnected.

\section{Dr J. A. K. Hamilton (F)}

I wish to offer my congratulations to the Authors for the very interesting Papers they have given.

D52. I am surprised that the decks of both the Forth and the Severn bridges have footpaths on the side. Those on the Forth Bridge are available to pedestrians and cyclists and the cost per crossing of a cyclist or pedestrian must amount to many pounds. I think cyclists and pedestrians should be provided with other means of transport.

D53. Mr Hyatt in his cable spinning carried two loops of wire across the Severn. The same equipment on the Forth carried four. Perhaps this is because, although he carried fewer tons of wire per hour across the river, he did it with a smaller labour force. Identifying eight wires going across the bridge and dealing with them individually takes a great deal of labour, and may be it is more economical to take two loops across instead of four. I imagine this would not apply if we were building suspension bridges of this magnitude every year, but teaching labour to deal with four loops of wire efficiently takes time.

D54. The tower plates on the Severn Bridge are large and had very considerable wind area. I think the wind conditions at the Severn were much better than at the Forth, but they must have caused anxiety in controlling some of these plates. What was the maximum wind speed under which it was safe to erect the tower plates?

D55. At the Severn the hanger ropes vibrated under certain wind conditions. This was effectively cured by putting dampers consisting of bob-weights on the arms. Is this the only answer? It might be possible to design a wire strand that would not vibrate, when we know enough about their aerodynamics.

D56. When going over the Salazar Bridge in Portugal I noticed there was a complete laboratory with an engineer in charge on one of the piers. The laboratory contained a number of instruments which recorded measurements of the bridge structure, wind speeds, the number of vehicles which crossed, deflexions both horizontal and vertical, and so on. I think that we could have provided similar laboratories both on the Forth and on the Severn bridges, or at least on one of them.

\section{Sir Harold Harding, Past President}

In $\S 9$ of Paper 7119 there are two important lines which might be overlooked. They describe the effect of resonance on bracing induced by the tidal flow in the Severn. It is important as the contractors found who were boring in the Channel Tunnel site investigation in 1963. Ten inch lining tubes were bored into the sea bed and had to stand up $100 \mathrm{ft}$ or more. On half a dozen occasions when the boring craft returned, after having been driven off by wind, it was found that the tubes had snapped, due to vibrations caused by the tides in the Channel, and this had been unexpected.

D58. In a paper which I presented to the conference on the highway needs of Great Britain in 1957 on 'The resources available for extensive highway construction and methods of handling a large programme', which was written before a decision had been made on either bridge, I said, 'A team of specialist labour must be trained for spinning the cables, for work of this magnitude is fairly novel in Britain. British labour can be quickly trained on unfamiliar techniques, but it would be wise so to stagger such work that the labour force can move from bridge to bridge with some continuity ahead in which to exercise their new skills.' Would the teams that moved from the Forth to the Severn Bridge as suggested be able to transfer to the Humber Bridge or have they been dispersed? 
Mr J. K. Anderson, Anderson, Dailey \& Clarke

I should like to pay tribute to the late Sir Ralph Freeman and Sir David Anderson: two great engineers who I feel contributed a great deal to what went before the design of this structure.

D60. Very little has been said about the history of this project, and it would be rather interesting if the Authors could perhaps say something about that. I remember Sir David Anderson with his dry Scottish humour saying in relation to the Forth and Severn Bridges he wanted the Scottish bridge to be longer than the English bridge ! At one time the two bridges were designed to have the same span so as to enable certain of the details to be similar. The spans of the two bridges were in fact to be $3000 \mathrm{ft}$, and then they were increased to $3300 \mathrm{ft}$. The Severn Bridge span was then reduced by some $60 \mathrm{ft}$ because the foundation conditions on the Aust site were found to be better nearer the centre of the river. It would be interesting to learn more about that from Sir Gilbert Roberts.

D61. I wonder whether, if a suspension bridge were to be built with a view to duplicating it at a later date, Sir Gilbert would design it with conventional stiffening trusses which could be converted to have a second deck, or whether it would have a box design along the lines suggested by $\mathrm{Mr}$ Berridge. There are one or two cases of double deck suspension bridge. The most famous is perhaps the George Washington Bridge in New York which has a span of $3500 \mathrm{ft}$, and was originally built without any stiffening truss. To increase its traffic capacity, a stiffening truss and second deck were added in 1960. The Verrazano Narrows Bridge at New York with its central span of $4260 \mathrm{ft}$, finished in 1964, was provided with a stiffening truss with steelwork for a second deck, to enable traffic capacity to be increased later. I think the tremendous confidence gained with having no stiffening truss at the George Washington Bridge may have led to over confidence on the part of the Americans and the great reduction in size of stiffening girders on certain bridges, leading to the Tacoma disaster and strengthening of the Bronx-Whitestone Bridge stiffening girder.

D62. When I was associated with the Tamar Bridge we considered the alternatives of having steel or concrete towers, and designs on both lines were produced. Concrete towers had been adopted in the Tankerville Bridge. It is difficult to know where the dividing line comes. The time may soon arrive when, with the great advance in concrete techniques, concrete towers may in fact be less costly. They were in the case of the Tamar Bridge and presumably at Tankerville.

\section{Dr T. A. Wyatt, Imperial College of Science and Technology}

I wish to refer to the use of the twisted wire strand in the inclined hangers of the Severn Bridge as a means of obtaining energy dissipation, or damping oscillation of the structure. This property of wire ropes has been known previously, but as far as I am aware there has been no public discussion of how this action in fact takes place.

D64. In tests, the energy dissipation per cycle diminishes during the first few cycles, but fairly quickly reaches a steady level. I feel we should be more confident in assuming this level in design if we could understand how the energy was being dissipated, and thus be satisfied that the factors involved would persist throughout the life of the structure.

D65. The behaviour of the wire strand is that when the end is pulled, the wires, being twisted into helical form, pull up tight and grip one another. The contact stresses generated are proportional to the tension and to the square of the ratio of diameter to the pitch length. Energy is dissipated by the friction forces set up by these contact stresses, in conjunction with the relative movement between the wires caused by the small change of the angle of lay resulting from elastic extension of the wires and from contraction on the diameter.

D66. This leads to the suggestion that the proportion of the maximum stored 
energy that is dissipated per half cycle of oscillation (which is the factor discussed by Sir Gilbert Roberts in $\S 20$, Paper 7138) is equal to

$$
\mu K\left(\frac{\text { mean stress }}{\text { range of stress }}\right)\left(\frac{\text { strand diameter }}{\text { lay length }}\right)^{3}
$$

in which $K$ is a factor depending on the way in which the contact stresses are distributed between the wires and $\mu$ is the coefficient of friction between the wires.

D67. The results of the tests carried out in conjunction with the Severn Bridge design show reasonable agreement with these ideas, at least for strands of fairly long lay length (say 12 diameters), but the results are perhaps not so sensitive to the lay length as I have suggested.

D68. The most significant possible disadvantage in the use of wire strand for damping is that for very small ranges of stress the frictonal forces may be sufficient to prevent the relative movement altogether and the damping behaviour is then inoperative. There is thus a threshold amplitude, which unfortunately in the theory is very dependent on the way the forces are distributed between the wires. The threshold is certainly low, not more than 1 ton/sq. in. stress range, which means there will be no structural danger before the strand works as a damper, but the oscillations may be sufficiently large to be noticeable to users of the bridge.

\section{Mr R. E. Knox, British Ropes Ltd}

There is a great fund of information on the hysteresis characteristics of the strands in use on this structure. I would agree with the formula put forward for a brand new strand; however, these units are fully prestressed and the generation of bearing areas to resist circumferential pressure has been done in the works before any testing for hysteresis value has taken place. There is no further reduction in diameter other than that normal for the elastic extension of the strand.

D70. Our tests indicate that there has been no falling off in hysteresis characteristics after the first application of load; it is just that the hysteresis value is generally better in the low range of stress.

\section{Written contributions}

\section{Mr C. A. Miller, Ministry of Transport}

In $\$ 7$, Paper 7138, Sir Gilbert Roberts states that 'an accident provided an opportunity to test a completely new concept'. If the model under test had not failed, what is the probability that the new concept would have been seriously investigated?

D72. The deck cross section evolved is a most satisfying solution to the design problem, and also to that of future maintenance. It is perhaps unfortunate that the innovation arose, not as the result of a full-scale investigation to prove box sections, but merely to occupy time provided by an unexpected break in the testing of a more conventional design. Had the Consultants intended to test the box section as soon as a suitable occasion arose to use it, on some future bridge?

\section{Mr R. Irwin-Brown (F)}

During the discussion I was struck by the spirit of friendship and regard between the senior members who were present. The names of Crosthwaite, Gowring, Harding, Hyatt, Pain, Roberts and Shirley-Smith were mentioned. Although they have gone their different ways it is indeed remarkable what a vintage period it was at the City \& Guilds around 1920, and how much is owed to Sir Ralph Freeman and Professor Dixon for their subsequent guidance of some of these gentlemen. Having had the privilege of knowing or working with several of them it seems to me in my forties that this generation of talent now in their sixties will be difficult to replace. Could the 
Authors say how they would suggest that a comparable nursery could be re-created for those now in their twenties?

D74. I feel that the late Mr Vernon Bartlett's, partner of Mott, Hay \& Anderson, contribution to the substructure contracts on the Severn and Forth should not be forgotten, and in particular how his appreciation of the physical and marine problems helped to lead to a successful outcome.

D75. May I also suggest that Sir John Howard's own contribution should be acknowledged. The fact that his company ably completed both the Forth and Severn foundation contracts on the basis of firm price competitive tenders is no mean achievement and is a measure of his own determination and enterprise.

D76. It has always seemed to me to be an anomaly that the extremely hazardous substructure works on both the big British bridges were the subject of competitive risk bearing tenders whereas the steelwork contractors could not lose. While I know there are special arguments in both these cases, I, too, should like to urge the merits of the target form of contract. The Institution is currently reviewing the standard Conditions of Contract, but I would have thought that equal and urgent attention should be given to the preparation of a form of target contract with provision for an element of competition that would be acceptable to the profession and the industry for civil engineering works of this character. The hybrid of varied contract conditions that was adopted on these two bridges may not be so succcessful on another occasion.

\section{Mr P. G. Buckland, Assistant Project Engineer, Swan Wooster-CBA}

What was the extent of the vertical curve of the roadway, apparent in Fig. 2 of Paper 7138 , and were the approach gradients the same on both sides?

D78. Cycle and footway tracks $12 \mathrm{ft}$ wide (effectively $14 \mathrm{ft}$ ) seem quite excessive. Is there really sufficient footway traffic over about two miles of bridge in this remote area to justify the size? I know of no other major bridge in the world with footways over $5 \mathrm{ft}$ wide (except the Forth). Had these been $5 \mathrm{ft}$ wide, saving about $7 \mathrm{ft}$, the saving at about $22 \mathrm{lb} / \mathrm{sq}$. $\mathrm{ft}$ for steelwork would presumably have been roughly 720 tons, or about $£ 135000$ for the suspended steelwork alone. Including the savings in the cables, towers and approaches, this would seem to amount to about a third of a million pounds. Although not mentioned, it is presumably possible that the $12 \mathrm{ft}$ width could be used as a lane for vehicles at some future date. If so, however, it will be a poor arrangement, and might not the money have been put to better use ?

D79. There are two apparent inconsistencies, which might perhaps be explained. In $\S 37$, Paper 7138, the maximum cable tension is given as 11400 tons. In $\S 13$, Paper 7119, the maximum tension is given as 10500 tons. Also in $\$ 43$, Paper 7138, the working load of the hangers is given as 100 tons and their breaking load 225 tons, whereas Table 3 gives the working load as $0.4 \times$ breaking load, which would be 90 tons.

D80. For the Forth Bridge cables a working stress of 40 ton/sq. in. was used on the assumption of 75 ton/sq. in. for the proof stress. For Severn, after finding that the proof stress was $4 \%$ higher, the working stress was raised by $12 \frac{1}{2} \%$. What brought about this effective increase?

D81. The subject of allowable stresses for bridges with high dead load to live load ratios is an interesting one, and in America it is common to increase the allowable stresses for certain parts of the structure. There is no American or Canadian bridge code to cover long span bridges and every authority and its engineers have to consider each case on its merits. My Company is currently investigating the conditions for a major bridge in Canada, and while our recommendations are in basic agreement with the criteria adopted in Paper 7138 and BS 153, there is one difference. The stress factor is 1.00 for dead load plus live load (HA) and 1.10 when full temperative effects are added. The latter figure presumably is taken because of the remote possibility of full loading and extreme temperature occurring together. No doubt it is quite as common to have full loading and a temperature from, say, $38^{\circ} \mathrm{F}$ to $75^{\circ} \mathrm{F}$ 
as it is to have full loading and $68^{\circ} \mathrm{F}$. There is therefore an inherent overstress at $38^{\circ} \mathrm{F}$ which is not permitted at $68^{\circ} \mathrm{F}$, in which case perhaps dead load, live load and half the temperature effects should be the basic loading combination.

D82. What tolerances were permitted on the $60 \mathrm{ft}$ sections of suspended deck?

D83. Table 1 of Paper 7138 gives a wind load on the suspended structure of $160 \mathrm{lb} / \mathrm{ft}$, whereas BS 153 would give $300 \mathrm{lb} / \mathrm{ft}$. Obviously the shape is of major importance. Some codes, such as the National Building Code of Canada, take the shape of a structure into account when determining the wind load, with enormous variations for a given area. Does the Author consider that a similar approach could profitably be used for bridges?

D84. Figure 10 infers that on the narrow tower plates, the bulb flat stiffeners butt directly onto the stiffeners of the next plate, whereas on the wider plates they terminate at the end transverse stiffeners. What are the reasons for this difference?

D85. A coefficient of friction of an anchorage on rock of 0.3 is given in $\$ 14$, Paper 7119. What safety factor could be considered likely using the figure ? It is interesting that the Verrazano Narrows Bridge uses the same value, but there the anchorages are founded on sand and gravel. ${ }^{\mathrm{D}}$

D86. Why did the cable levels affect the use of the work cars ( $\$ 55$, Paper 7084)? Were the work cars not used later to support the spinning machine?

D87. It must have been disappointing that automatic welding could not be used in all cases where it had been hoped to do so. West of the Atlantic it is almost essential to use automatic welding if this type of construction is to be economical and acceptable. From the experience of this bridge could the Authors suggest ways in which the weld preparations could be improved to permit satisfactory automatic welding?

Mr D. P. Powell, T. P. O'Sullivan \& Partners

I should like to comment on the Aust Viaduct and the design of the box girders (Paper 7119).

D89. Calculations for the deflexion at various stages of construction were extremely lengthy due to the complex variation in top and bottom flange plate thicknesses from box to box. Observed deflexions also varied from the calculated ones. The necessity for packing plates and different length friction grip bolts at the joints arising from this complex variation could also have given rise to confusion, particularly as there were several hundred bolts in some joints. Do the Authors consider that the cost of the extra steel necessary to provide a uniform section throughout would not have been offset by the saving in fabricating costs resulting from the use of a simplified uniform section throughout?

D90. In support of this it may be worth recalling that in many existing parapet girder-cross girder type bridges built some time ago it is quite common to find built-up parapet girders, but nowadays it is not as common a practice to design compound girders when similar site conditions prevail, even though they may be 'economic' in design.

D91. Could a small saving in erection costs have resulted also from the use of boxes of equal length?

\section{Mr D. G. Calder, Bridge Structural Engineer, Swan Wooster-CBA}

There are several questions I should like to raise on Paper 7138.

D93. The first concerns the combination of stresses on the towers. It would appear that the axial stresses in the tower are about $13 \mathrm{ton} / \mathrm{sq}$. in. under the saddle and $11 \mathrm{ton} / \mathrm{sq}$. in. at the base. These are approximately $50 \%$ greater than for the Forth and are obviously not derived from the Perry-Robertson formula of BS 153 . Presumably, since an allowance for imperfections is made in the bending stresses, the permissible axial stresses are derived directly from the Euler buckling load for the 
tower leg. If so what factor of safety was used on the Euler load? Was this approach used on the Forth towers?

D94. The side plates of the tower have a critical buckling stress of 40 ton/sq. in. representing a factor of safety of 3 on maximum design stress. Was this buckling stress an 'ideal' buckling stress or did it include consideration of the tangent mod:Ilus?

D95. The imperfections in the tower were catered for on the Forth by a 12 in. addition to the tower deflexion and on the Severn by a 6 in. addition to the deflexion. Does this change represent more confidence in the contractor's ability to construct the towers or is it related to the height and live load deflexion of the tower?

D96. Does the streamlined shape of the deck cause any increased wind effects on traffic?

D97. What advantages are gained by having a target cost erection price when the remainder of the supply is fixed rate? The contractor's profit was apparently increased by $60 \%$ as a result of being considerably under the target. This would indicate a conservative target figure originally, and it would appear that a competitive tender would have produced at least the same saving to the client and possibly more at the expense of the contractor's extra profit. Is it felt this type of contract affords the contractor protection against loss and guarantees the client a finished structure?

D98. With regard to Paper 7084, I wish to ask the following questions.

D99. During fabrication of the tower legs, the four sides were milled to length independently and only the surfaces in contact with the saddles were machined as a unit. From the details and the construction method each plate is butted to the previous member in a freestanding condition without shimming. It would appear therefore that by the time the upper sections are reached there would be minor out of levels in the final machined surface requiring some form of shimming. If so, then the machining of the top surface as a unit in the shop would appear unnecessary. Were such shims required?

D100. How was the tower checked for verticality during construction when the climbing structure and later the dampers produced such noticeable deformations?

D101. Having had the good fortune to spend two years in the ABB London office working on the planning and design of temporary works, I would be interested to know how close the final midspan roadway level agreed with the level in the engineers' drawings since this is dictated purely by the cable spinning strand adjusting calculations and site adjustments which were carried out at such an early stage in the contract.

\section{Mr G. W. Morley, formerly Chief Engineer, Associated Bridge Builders Ltd}

I should like to emphasize the value of the deflexion model of the bridge referred to by $\mathrm{Mr}$ Hyatt in $\S 71$, Paper 7084, of the studies of the behaviour of the river mentioned in $\$ \S 67$ and 68 , and of the aerodynamic investigations of erection conditions carried out by the NPL at the instigation of the contractors.

D103. The deflexion model was basic to the discovery of all the movements and shapes to be expected during the erection of the suspended structure, later evaluated by the computer calculations which were themselves guided by model results. It also led to many of the major decisions concerning the erection method, e.g. it showed that it was not necessary to balance main span erection by the side spans; therefore only two sets of erection equipment and two erection fronts were necessary; therefore only two slipways were required for assembly of deck sections; therefore the two existing slipways at Chepstow were sufficient and the search for an alternative site suitable for four slipways could be called off; and so on.

D104. The model was two dimensional with a single piano wire representing the cables, nylon threads for the suspenders, single rectangular machined rods clamped rigidly at their lower ends for the towers, and little blocks of timber and steel which could be hung on the suspenders and pinned to each other to represent the deck 
sections. I believe the model was about $35 \mathrm{ft}$ long to a scale of 1 to 150 (not 1 to 50 as stated in Paper 7084). It was built in the Whitehall office and hung at a high level across one large room, through the corridor, and into another room where the anchorage interfered to some extent with the work of the purchase clerk! While it was necessary to hang deck sections at any point along the model, all measurements could be made and shapes observed in the large room which held slightly more than half the model. The greatest problem was to ensure that the points of attachment of the nylon suspenders to the steel piano wire did not slip.

D105. In considering the problems of erecting the suspended structure it was realized from the beginning that the currents and tidal range of the river would play a major part. Before any tender was submitted, rather crude experiments were carried out with barges and tugs on the site to see whether there was a reasonable possibility of holding a section steady for the time necessary to attach the lifting tackles. In the beginning opinions regarding this time (for four tackles) varied between one half and one hour; in the event the time taken (for two tackles only) was only a few minutes. At the same time the Hydraulic Research Laboratory's model of the Severn Estuary was visited at Wallingford and a visual study made of the current conditions under all states of the tide. It was realized that reasonably slack water could only be relied upon on the crests of the neap tides, and then only for very short periods.

D106. At commencement of planning an American paper ${ }^{D 2}$ concerning their Mohole experiment in preparation for drilling through the earth's crust was noticed. This describes how the drilling ship was held in position over the hole by means of four outboard engines of the Harbourmaster type. Enquiries in this country for similar units led to the 17 Port Regiment, RE at Marchwood, who agreed to carry out simulating trials in Southampton Water. These showed the potentiality of the type of equipment for the solution of our problem. The Regiment transported their gear to the site at Beachley and carried out further trials there at our request. As a result, it was decided this type of gear could be successfully adopted, and to develop a tug, or pusher barge, equipped with Harbourmaster engines to control the floating sections.

D107. Thereafter the 'Severn Knave' evolved logically with its four Harbourmaster units, two anchor winches, derrick mast, fire-pump, navigation bridge, and so on, all in their proper logical positions and with their essential functions. Most of the credit for the development of this unique craft must go to the Marine Consultant, Mr Murray Taylor, who spent many days studying the behaviour of the river at the site and on the model at Wallingford, and investigating the characteristics of the floating sections in the ship tank at the NPL. He also supervised its construction by Charles Hill \& Sons at Bristol, and carried out a series of manoeuvrability trials on the Avon and at the site.

D108. Having ensured that the floating sections could be adequately controlled on the river, the next problem was to lift them into position. This started as a four point lift, using two heavy lifting beams, but developed into a two point lift to ensure that each tackle took only $25 \%$ of the load and a single balanced lifting beam to reduce the amount of temporary steelwork required. With a two point lift it became essential to check the aerodynamic stability. As a result of model tests by the NPL, the lifting and stabilizing systems shown in Figs 16(a) and 16(b) and described in $\$ \$ 74$ and 75 of Paper 7084, were evolved from earlier conceptions. It was demonstrated that, with these simple arrangements, any of the sections could be lifted with complete confidence in any likely wind conditions, and would not become unmanageable if conditions deteriorated during the course of lifting. The use of Lebus grooves on the drums of the lifting winches ensured perfect winding of the ropes up to ten layers in depth.

D109. When suspension bridge decks are being erected the structures initially develop excessive sags, making it impossible to complete the permanent connexions 
between parts. In this case the deck sections would hang like beads on a string, touching only at crown of roadway. Here again was a problem for the NPL because although the completed bridge had been tested for stability the string of beads had not. As Mr Hyatt has described in $\$ 75$, the NPL predicted classical flutter at wind speeds well below $100 \mathrm{mile} / \mathrm{h}$. This was overcome by the installation of flexible connexions designed by the engineer to give sufficient torsional stiffness to the system.

D110. Without the thorough investigations carried out by, or for, the contractor into the behaviour of the river, the effects of the river and of wind on the sections, and the wind effects on the partially built structure, the erection of this bridge at the Aust-Beachley site would have been extremely hazardous. By applying the lessons of these investigations it became simple. I would like to suggest that more should be done in this respect for large span bridges projected for other sites; it is not sufficient to show that they will be stable when completed; all parts and build-ups must also be stable during erection.

\section{Sir Gilbert Roberts}

In reply to Professor Pugsley's remarks on the design wind speed, we used $100 \mathrm{mile} / \mathrm{h}$ at deck level, corresponding to $90 \mathrm{mile} / \mathrm{h}$ at the standard height of $10 \mathrm{~m}$, on the advice of the Meteorological Office. This was probably intended to apply to a gust of 3 or $5 \mathrm{~s}$. Although the gust at Avonmouth (and perhaps at the Severn crossing, too) might reach $115 \mathrm{mile} / \mathrm{h}$ for $3 \mathrm{~s}$, this is not relevant to the design of the whole bridge. To be effective it would have to be not only of longer duration, but also acting on a considerable length of the bridge.

Dr Wyatt mentioned that the duration of a gust is now considered to be related to its size and in his view a gust of at least 20 s duration would be required to load a quarter of the length of the bridge. In Appendix 1, in which we describe the results of recordings of wind speed, direction and inclination, it can be seen that we adopted a duration of $30 \mathrm{~s}$ and threequarters of the span as the criteria for effectiveness of a gust. The possibility of shorter and therefore smaller gusts of higher speed is not significant in the design of a large suspension bridge.

On reflection one is struck by the lack of detailed information on wind behaviour, particularly over those stretches of water where long suspension bridges are proposed. We were fortunate at the Severn in having the Sharpness Bridge on which to put recording instruments to get some indication of the wind pattern over two or three years. At most other sites there is no possibility of similar measurements. I hope one day it may be possible to derive some curves or formulae from which one can estimate the wind behaviour over a suspension bridge site by reference to the meteorological records and the local ground contours, which obviously have a major influence on the disturbance of the wind.

The Stockbridge dampers designed for the hanger strands weigh $39 \mathrm{lb}$ each.

In the first suspension bridge design that I worked on in 1928 (the first Forth Road Bridge!) we used 30 ton/sq. in. on spiral strand, presumably to allow a factor of safety of 3 on the breaking load. Later we used 35 ton/sq. in. for parallel wire. On recent American bridges the stress has been $38 \mathrm{ton} / \mathrm{sq}$. in. and when we started on the Forth Bridge we used 40 ton/sq. in. Nevertheless, it seemed to me that with such a uniform and satisfactory material as drawn wire subject almost entirely to dead load, it would be justifiable to use no higher factor of safety than on the structural steel, which is subjected to variations in stress and uncertainties of live load. So in the Severn Bridge we decided to increase the working stress to 45 ton $/ \mathrm{sq}$. in.

In a suspension bridge the resistance to deflexion comes almost entirely from the horizontal component of cable tension, $H$; the stiffening truss has a small effect, not more than $10 \%$. Increase of allowable cable stress reduces the weight of the cable and therefore $H$, so reducing the 'stiffness' of the bridge. Variation in working stress changes the economic proportions of the bridge; with higher cable stress a 
higher sag ratio is economic. So we increased the ratio to $1 / 12$ which raises $H$ (and incidentally the natural frequency) and results in some saving in height of towers and length of cable and hangers. This is one reason for the strikingly light towers at Severn compared with other bridges.

Mr Upstone made a good point in criticizing our $1 \frac{1}{2}$ in. of mastic asphalt surfacing. It is true that the surface of the steel plate deck when complete was a far better running surface than it is now with the asphalt on it. In fact it was better than the best motorway standard, according to the Ministry of Transport. I think the $q$ rating was something like 45 , which was very good, and when the mastic and the chips were laid it went up to 130, which was average. Even so it is not bad. It shows that if we could produce a thin coating of uniform thickness that would stick to the steel and be satisfactory as a wearing surface, it would be quite satisfactory from the bump number point of view-in fact, more so than mastic, and it would save a great deal of work. The saving in cable tension may be even more than the $6 \% \mathrm{Mr}$ Upstone mentions.

On another bridge where we are doing the surfacing in the same way, and where we are not subject to the prejudices in this country against thin coatings, we shall probably use $1 \mathrm{in}$. or less of specially graded, rolled asphalt laid by machine, and therefore obtain a much better running surface than we can get with hand laid mastic. I think that will be the next development. After that, perhaps one of the tile or flooring people will come up with something like linoleum to stick on.

With regard to preformed parallel strands, I can only say I think they are essential for building long span suspension bridges where you have only one to do. With two or three similar ones, it would be a proposition to buy the plant and use it for them all. With one only to do these parallel strands must be used, and there is a good possibility that they would be economical in any case. The limitation is the weight of strand in a coil that can be handled conveniently, and I have provisionally taken that as 35 tons. For that, on quite a long cable you get a reasonably sized bunch of wires. We shall know more about that soon.

I was sorry to hear from Mr Hugh Knox that the eccentric pin adjustment on hanger lengths was of no use. I thought they had made use of it on one or two occasions. I know they locked the pins to avoid sabotage.

The important thing in the design of the deck is the wheel load, and the area over which it is spread. As far as the bending on the deck plate is concerned, the AASHO loading is more realistic than the $\mathrm{HB}$, and might allow a reduction of $1 / 16$ in. in plate thickness, but it is doubtful whether you would want to reduce plate thickness from 0.45 in. After all, there is a possibility of corrosion in future if the plate is neglected. Theoretically the American loading would allow a small economy to be made, perhaps $2 \%$ on the whole job.

Mr Berridge wants to drive a horse and cart through the inside of the box, and Mr Anderson mentioned the possibility of increasing traffic capacity by adding traffic lanes at a lower level. The disadvantage of running traffic inside a box is that it is no longer sealed. You have maintenance to do on the inside where it is not so easy to paint because of the stiffeners. It is better to seal the box up, and preferably weld the manhole covers so that people cannot get in to see how it is progressing.

Another point is that approaches to the bridge get awkward with traffic at two levels, and it is impossible to allow for 'tidal flow' by having more or fewer lanes in one direction morning and night. With six lanes it is probable that you are near the capacity of the traffic wanting to cross the river at one point. Twelve lanes may be economic for the bridge, but it would be difficult to deal with so much traffic at one point on the bank. I would personally prefer to have a bridge with six lanes, and when that is full up, build another bridge at a different point.

Mr Scruton mentioned torsional interconnexion adopted during erection. That was done by a simple device that we designed which consisted of projecting plates 
down the sloping side of the box, projecting about 6 in. with connecting holes at the edge so as to allow breathing longitudinally but giving torsional rigidity. On a similar job we should pay more attention earlier to the temporary attachments between boxes when they are first erected. Our scheme of construction was not the ideal for providing a strong connexion at, say, two points near the surface of the deck which would take longitudinal and torsional stresses between the sections and, at the same time, allow vertical bending flexibility.

Mr H. Knox mentioned the relatively large number of men required to service the welders and erectors. With a better system of temporary connexion I think the amount of labour could be considerably reduced.

Dr Hamilton decried the use of footpaths on the bridge. When you see a bridge crowded with traffic and two footpaths at least $10 \mathrm{ft}$ wide with nothing on them, you wonder if your calculations have gone wrong. All the bridges I know of, except one, have footpaths of some sort provided, and on the Severn and Forth Bridges they are very useful for the maintenance vehicles and for conveying visitors across the bridge in your own car! Without a footpath, I think you would need a greater width on the deck, and on the exceptional bridge I am thinking of there are eight lanes, the outer lane being $14 \mathrm{ft}$ wide instead of $12 \mathrm{ft}$ which gives the extra margin to walk along.

The recording laboratory on the Lisbon Bridge is interesting. I do not know what they are recording, although they have earthquakes there.

Mr Kenneth Anderson raised the question of the span length. Both the Forth and the Severn started at $3000 \mathrm{ft}$. At the Severn the position of the west pier was fixed by agreement with the river authorities and the ferry owners. A more careful survey showed that a $3000 \mathrm{ft}$ span would put the English side pier at the bottom of a deep gully, and another $300 \mathrm{ft}$ was needed to put it on the Ulverston Rock. As a bit more span would not harm the Forth Bridge either, Sir David Anderson increased that to $3300 \mathrm{ft}$. However, a more careful survey showed that the mound on which the west Severn pier was to be founded was not as we thought, and we had to move it back slightly. Everyone was delighted because it made the English bridge $60 \mathrm{ft}$ shorter than the Scottish one!

In reply to Mr Miller's question, the box section design would have been investigated in any case but perhaps too late for incorporation in the Severn Bridge. It must be remembered that these investigations are expensive and it would not have been easy to justify a completely new investigation when the existing one was barely finished. There was no assurance that the extra cost and delay involved would be justified by the result. Our associated consultants were not in favour of the change and the contractors would also no doubt have preferred a construction similar to the Forth Bridge.

Mr Buckland considers the footway and cycle track are excessively wide, but in practice the width has been found invaluable for the passage of maintenance vehicles which otherwise would have to travel on the two-lane carriageway. In a recent design for a similar bridge the side tracks have been made $2.5 \mathrm{~m}$ wide for the same reason.

The figures for stresses in the cable and hangers are correct as given in Paper 7138 . The cable tension varies with the slope and is less than the maximum at the anchorage.

The values in the working stresses in the different parts of a suspension bridge are a matter of engineering judgement in which the type of loading and probability of different combinations of loading must be considered. There seems no reason for a higher factor of safety on the cable wire than for other parts of the structure.

The design of the box is such that exact lengths of the deck section are not required. The longitudinal stiffeners on the tower plates butt directly on to the stiffeners on adjoining plates in all cases. This is obviously essential for transfer of stresses without cover plates. Fig. 10 is incorrect.

The reason for abandoning automatic welding for the bottom flange of the box 
after erection was that there was too much water, dirt and oil in the joints for the $\mathrm{CO}_{2}$ process intended. Since adequate cleaning was impossible at that stage the welds were made with hand electrodes which are more tolerant of such conditions. This could be avoided with another type of butt joint and automatic or semi-automatic welding should be feasible.

In reply to Mr Calder, the width of the tower at the base is determined by erection considerations, and the strength of the tower as an Euler strut does not arise. The sides of the tower are subjected to direct stress only, for which the allowable limit is $13 \frac{1}{2}$ ton/sq. in. Allowance for 'tangent modulus' is not necessary; careful compression testing has shown that specimens cut from plates up to $\frac{7}{8}$ in. thick have a linear stress-strain relationship up to the yield point.

The 'imperfection allowance' of $6 \mathrm{in}$. was less than that allowed at Forth, partly because the towers are lower and the side spans shorter and partly because the dead load of the deck could be more accurately assessed. The cross section of the box is uniform throughout, whereas on Forth the side spans have a concrete deck.

The streamlined shape does not increase the velocity of the wind blowing across the deck, but there is no protection from the wind such as may be provided on other bridges by stiffening trusses or solid parapets.

The advantage of the target type of contract is that it may encourage a capable contractor to 'have a go' at a job of a type unfamiliar to him for which he would not submit a fixed price for fear of crippling losses. In such circumstances any fixed price quoted is likely to include such a generous item for contingencies that it would be uneconomic.

In reply to Mr Calder's last two questions, the towers could not of course be checked for verticality during erection but in the finished bridge they are vertical within the limits of accuracy of the temperature measurement. To make a precise measurement it would be necessary to determine accurately the temperature of the steel throughout the structure within a few degrees Fahrenheit, which is not practicable.

\section{Messrs Gowring and Hardie}

In reply to Mr Powell, the saving in the weight of structural steel achieved by the use of flange plates of varying thickness was at least 70 tons, and we consider that this saving amply justified the additional complication of having to use packs and bolts of varying length. The calculations for deflexions are more complicated when the beams have varying fianges, but with the use of computers this does not represent much extra work or cost. If flanges of equal thickness had been used throughout, then it would have been reasonable to use boxes of equal length. However, since the flange thickness varied, it was decided to use boxes of approximately equal weight in order to economize in the cost of the erection equipment. It should also be pointed out that the longer the span of a bridge, the more important it is to keep the self weight as low as possible and in the case of the Aust Viaduct; in the erection condition at least, the weight of steel in the box beams is a major part of the self weight. We also consider that there would not be sufficient repetitive fabrication to offer cost saving.

\section{Mr Hyatt}

Sir Hubert Shirley-Smith remarked on the equipment from the Forth Road Bridge and, as we were all jointly concerned with both bridges, we were naturally glad to make use of our experience on the first bridge for the benefit of the second. I think that the gear was overhauled after it left the Forth site, and that the wrapping machines were completely rebuilt. I fear that there would not be much left from

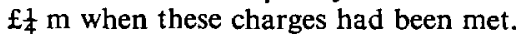

The slight increase in the cable voids percentage compared to Forth (about $0.7 \%$ at cable bands) was to be expected as due to the fact that each cable contained 19 
large strands instead of 36 smaller ones and wire movements under compaction were greater. The voids ratios in various parts of the cables varied on both bridges and the average throughout was found the same in both cases.

So far as using pontoons for floating out is concerned, it avoids the sections spending a long time in the water before lifting. However, on this site it would have been difficult and expensive to arrange storage facilities on land and the extra costs of pontoons and jetties would have been considerable. In fact the characteristics of the sections made the arrangements used very attractive. Mr H. S. G. Knox has referred to the possibility of erecting two or three sections a day which has a bearing on this point as launching equipment and pontoons would have to be doubled or trebled for this to be feasible if sections were not self-floating.

On safety, the agent was much involved and his authority extended to this as in all other aspects of the work. However, I am sure that it is wrong for someone who is frequently absent from the site to try to run the safety committee. This committee was a strong one at Severn and results speak for themselves.

Reference to painting gantries is found in Paper 7084 and they were delivered early enough to be of use during construction.

Sir Hubert referred to the catwalks on the new suspension bridge at Quebec. These are replicas of those used at Severn and the Consultants are favourably impressed with them in spite of departures from normal American practice.

Mr Crosthwaite referred to the target contract, as have Mr Irwin-Brown and Mr Calder. I feel that this type of contract has great merits for works of this nature, particularly when new developments are in hand. It has worked very well on the two bridges but it depends on an honest estimate being made and the employing engineers being able to vet it carefully.

$\mathrm{Mr}$ Crosthwaite also referred to the partnership of engineer and contractor, of which fact we were all deeply sensible. His firm has always had the deserved reputation of bearing erection problems well in mind in their designs.

The aerodynamic problems are referred to by $\mathbf{M r}$ Scruton and all concerned gratefully acknowledge the indispensable help given by him and his colleagues at the NPL.

The use of parallel wire strands, as mentioned by Mr Upstone, has been successfully employed in America on one recently constructed bridge of medium span, although some quite serious problems were encountered. This is only to be expected with a new process and I feel that the matter is well worth pursuing as possibly leading to economies in time and money.

Mr Holland, Mr Ford and Dr Hamilton referred to the question of two bight versus four bight spinning. This was discussed at length before work was started at Severn. The fact that there is considerably less wire in the Severn Bridge cables and there were, in effect, only three spans instead of five as at Forth, indicated that the extra time needed for training to four bight spinning would not be worthwhile. In fact, the saving in labour cost was considerable and the man hours per ton at Severn were about $30 \%$ less than at Forth. The rate of spinning was still rising when the cables were completed. Two bight spinning is normal in America and it is preferred there to spin two bights from each end rather than four from one end for large cables.

The use of heavier bridge wire for cables requires serious consideration and experiment both in production and spinning. I think that the block diameter for the coils would have to be increased and all drums and sheaves of the spinning gear would have larger diameters and weights. I imagine that the size of strand shoes would also have to be greater. The techniques of handling the $0.196 \mathrm{in}$. dia. wire have been well established and necessary alterations might not be worthwhile in view of the comparatively few uses made of the system.

With reference to the control of the tower plates during erection, mentioned by Dr Hamilton, it was found that they could not be handled safely in winds exceeding 10 mile/h for lifts in the last few upper sections of the towers due to the difficulty in arranging guide wires as mentioned in Paper 7084. The use of a separate lifting 
device for each leg might have improved matters. This system was used for the towers on the New Quebec Bridge. The time lost at Severn on account of wind and rain was only about $11 \%$ of the total erection time as the internal bolting-up was not affected by weather.

Both Dr Hamilton and Mr Buckland query the necessity for footpaths and cycle tracks. These remarks should, presumably, be addressed to the Ministry of Transport. Certainly to North American eyes their width and even their provision at all appears questionable. However, at Severn they have a practical function as access tracks for maintenance and service vehicles which can operate without interrupting traffic.

In reply to $\mathrm{Mr}$ Buckland, I think that there were no official tolerances laid down for fabrication of the deck units but, in practice, we worked to plus zero minus $\frac{1}{32}$ in. in length and plus or minus $\frac{1}{3} \frac{1}{2}$ in. on widths of plates.

Cable band erection was carried out from work cars supported from the tram support strands whose hangers were disconnected from the footwalks on completion of cable spinning and compacting, except at the centre of the main span. The footwalks at this stage were carried by the main cables and moved with them and clearances became too great for convenience as the cables deflected under load. Avoidance of uncertainty for the positions of the cable bands with partially loaded cables was also a factor.

The question of weld preparation for the site welds is, I believe, still a matter for consideration. The permanent backing strips which were so useful during erection, could be replaced by carbon blocks or other temporary sealing, or by a sealing weld applied to the underside. Much more staging and temporary gantries would have been needed in this case and, with the comparatively short runs required, it is doubtful if machine welding would show a saving in these circumstances.

There is a strong case to be made for using bolts for these transverse site joints in box type construction in spite of admitted difficulties and aesthetic considerations.

Mr Calder suggests the use of shims under the main saddles at the tower tops as an alternative to machining the tower plates as a unit. I would not consider this to be sound practice in view of the heavy loading and accuracy required. In fact, no shims were used.

The tower verticalities were read by means of a theodolite with a $90^{\circ}$ eyepiece and an optical plumbing device registering on targets fixed to the tower tops.

Owing to the difficulty in estimating the internal cable temperatures, the finished levels of the main cable can only be stated as believed to lie between plus or minus $0 \cdot 10 \mathrm{ft}$ from their correct positions.

I am grateful for Mr Morley's further explanation regarding the deflexion model of the bridge which was so important to us and regret the misprint which indicated an incorrect scale.

I am pleased to endorse his remarks regarding the credit due to Mr Murray Taylor for his work on the river where his help was expert and invaluable.

It has been suggested that two further members of the Central Office staff should have been mentioned in the list of acknowledgements of Paper 7084. I have pleasure in putting forward the names of G. K. Tomlinson, BA (Cantab), AMICE, and D. G. Calder, BSc, DIC, AMICE, for inclusion and regret their omission from the original list.

\section{References}

D1. Just L. H. et al. Verrazano Narrows Bridge: design of tower foundations and anchorages. J. Constr. Div. Am. Soc. civ. Engrs, 1966, 92 (Mar.) No. CO2, 71-93.

D2. National Academy of Sciences. Experimental drilling in deep water at La Jolla and Guadalupe sites. National Research Council Publication 914. 